\title{
Local Tax Competition in Poland?
}

Abstract

The concept of tax competition has been successfully applied in an analysis conducted in several European countries, but so far it has not been systematically tested either in Poland or in other countries of Central and Eastern Europe. There are two types of competition discussed in the article: classic competition for mobile tax base and 'yardstick competition', in which local politicians compete for political capital being related to the comparison of tax rates with neighbouring municipalities. It is expected that in Poland the 'yardstick competition' is more important from the classic competition for the mobile tax base.

Keywords

Tax competition • local taxes $\bullet$ tax policy $\bullet$ local government $\bullet$ local finance - yardstick competition

(C) University of Warsaw - Faculty of Geography and Regional Studies
Paweł Swianiewicz

Julita Kukomska

Department of Local Development and Policy

University of Warsaw

e-mail:pswian@uw.edu.p

e-mail:j.lukomska@uw.edu.pl

Received: 17 January 2016

Accepted: 11 October 2016
Introduction

Tax competition is a theory which may help us to understand the spatial interactions behind the variations in local government tax policies. The aim of the paper is to examine how useful this concept might be in explaining the behaviour of Polish municipal governments.

Although the empirical study concentrates on Poland, it may have a wider importance for the whole region of Central and Eastern Europe. So far, the concept of tax competition has not been applied in Polish local government studies, and has very rarely been used in other countries of the region. One of the reasons for the low level of interest in local tax competition studies might be the limited tax autonomy of Polish local authorities. Even if local discretion to decide upon local taxes is limited in Poland, it is still greater than in most of the other countries of Central and Eastern Europe (see Šević 2008; Swianiewicz 2014). Therefore, empirical tests conducted on the Polish data may shed some light on the possible validity of the concept in the whole region.

The concept of tax competition - theoretical discussion and previous empirical studies

The model of tax competition was created to explain national tax policies, but it may be applied at the local level as well. Tax competition is defined in this paper as the situation in which the local tax rate in a given jurisdiction is changed as a reaction to the tax rates applied by neighbouring jurisdictions.

There are two different potential motives for tax competition:

- Competition for a mobile tax base, in which the local government tries to attract the movement of capital, companies or residents to a given jurisdiction. It leads to the growth of the local tax base and, in the ideal scenario, to the resultant growth of budget revenues. The positive impact on the local budget may be direct (increased revenues from the tax for which the rate is the subject of the competition) or indirect: for example, local jurisdiction attracts new tax-payers through a competitive property tax rate, which indirectly generates new income from other taxes such as personal income tax (PIT).

- Maintenance or increase of the political capital - tax rates are adjusted in the analysed jurisdiction, taking into account the tax rates of the neighbouring municipalities in order to satisfy local voters and to secure political support in local elections. In this case, one talks not about 'classic' competition for the tax base, but about the concept known in economics as 'yardstick competition'.

In the case of 'yardstick competition', there is no reason to expect that reduction of the tax rate may be compensated for by the growth of the local tax base. Rather, this situation relates to the exchange between financial and political capital (Mouritzen 1992). Political 'yardstick competition' emerges when the performance of the governments in various jurisdictions becomes sufficiently comparable so that the voters can make meaningful comparisons between jurisdictions (Bodenstein \& Ursprung 2005).

Blöchliger (2013), in his interpretation of the reaction of taxpayers to tax rates, refers to Hirshman's concept of exit and voice strategies. The exit strategy can be identified with the first of the two motives discussed above, since it assumes 'voting with the feet' and the movement of the tax base to another jurisdiction by 'members' who are not satisfied with the benefits of their membership of the club. On the other hand, the voice strategy (complaining, protesting) can be identified with the 'yardstick competition' in which tax-payers argue for lower tax rates by referring to the rates in neighbouring jurisdictions. In this situation, 'members' try to improve their position by expressing discontent and demanding changes in the tax policy. Blöchliger suggests that a tax-payer has three potential reactions to a tax rate he/she is not satisfied with: moving to another jurisdiction (exit), reducing effort (for example, not making an effort to earn extra income), and trying to avoid taxation (tax dodging). 
The debate on the value of local tax competition has been prolonged and has never led to a unanimous conclusion. Antagonists issue a warning of the danger of a 'race to the bottom' and the under-provision of public services (e.g. Oates 1972), while stressing that the dynamics of tax competition between subnational governments is such that a local authority will not improve its relative position within the country, and that no one will gain any long-lasting competitive advantage (Dafflon \& Rossi 2004). Protagonists' arguments are rooted in their belief in the value of competition, which helps to achieve innovations and obliges elected politicians to strive for allocative efficiency (Buchanan \& Musgrave 1999).

For further discussion, it is most important to identify the conditions that may increase or decrease the intensity of tax competition among local governments. The level of competition will depend on (Baur 2010; Tiebout 1956):

- Local tax autonomy - the more autonomy local governments have, the more likely tax competition is. It is also notable that the consequences of tax competition cannot be externalised. In particular, revenues from local governments' own taxes must not be substituted through financial transfers from higher government. If that condition is not followed, tax competition may be seriously biased,

- $\quad$ Structure of local taxes - the probability of tax competition is higher if local taxes have a mobile tax base (see also Brülhart \& Pratchet 2014),

- Territorial organisation - tax competition is more likely in territorially fragmented systems, which minimize barriers to the migration of residents and capital. Territorial fragmentation also makes it easier to compare tax rates in neighbouring jurisdictions (see the 'voting with the feet' model - Tiebout 1956),

- It is more likely to occur in smaller jurisdictions, where the economy is more open and they are more dependent on external investors (as is discussed for tax competition among countries - Elschner \& Vanborren 2009 - but the same concept is sometimes applied to subnational jurisdictions).

Building on the asymmetry of information between voters (tax-payers) and political representatives, Reulier \& Rocaboy (2009) also expect that decisions on the local tax rate will depend on the variation of rates among neighbouring jurisdictions. The greater the variation, the easier it is for politicians to apply higher tax rates in their own jurisdiction, since it is more difficult for voters to treat the surrounding region as a yardstick in the political debate.

European empirical studies suggest that tax competition on a local level really exists and can be identified in several cases - for example, in Finland (Moisio 2010), Belgium (Gérard et al. 2009), the Netherlands (Aalers \& Elhorst 2005), Switzerland (Baur 2010; Dafflon \& Rossi 2004), France (François 2010; Reulier \& Rocaboy 2009), Germany (Janeba \& Osterloch 2012; Kalb et al. 2012), and Denmark (Kleven et al. 2013). But Buglione \& Mare (2010) find little evidence of tax competition among subnational jurisdictions in Italy. Lyytikäinen's (2012) findings on Finland are similarly sceptical, but his research concentrates on property tax, which is a relatively minor source of Finnish local government revenues.

Comprehensive reviews of identified cases of local tax competitions are provided by Blöchliger \& Pinero-Campos (2011) and Blöchliger (2013). The dominant opinion suggests that local tax competition in European countries is very limited. There are at least two reasons explaining this opinion. Firstly, the tax yields and the discretion of local governments are limited in Europe. Secondly, central policies mitigate tax competition through a rigid system of norms related to local services (which demand a fixed level of local spending), as well as through vertical and horizontal equalization systems (Rattsø 2005).
So far, the numerous empirical studies of local tax competition in Western Europe have very few equivalents in Poland and there has been very little reflection on other countries of Central and Eastern Europe. One of the few exceptions is the work of Sedmihradská et al. (2016), who trace local tax mimicking in the Czech Republic in the decisions on property tax.

The tax literature in Poland has been dominated by the analysis of the legal background. Among the few studies of Polish local tax policies, the typology of policies proposed by Miszczuk (1995) in his study of the Lublin region should be mentioned. The variation in local agriculture tax was analysed on a very basic level by Podstawka \& Rudowicz (2010). Skica et al. (2011) analysed vehicle tax and its role in the stimulation of the local economy. But none of these studies have focused on the systematic analysis of local tax competition, which to date has only been mentioned in a small number of press materials.

Local tax competition in Poland - explanatory model and hypothesis for empirical tests

In Poland, the potential space for local tax competition is limited to the municipal (gmina) tier only. Neither of the two upper tier subnational governments - county (powiat) or regional (województwo) - have any discretion to decide upon the rates of any taxes. Even at the municipal level, tax autonomy is limited. Tax levels are capped by the 'ceiling rates' imposed by the Parliament, so local government decisions on tax rates are limited to the levying of the maximum possible or lower rates. Local governments may also grant tax reliefs or exemptions. The tax yields collected from local taxes provide a fairly modest part of local government revenues - on average, they make up about $20 \%$ of the total local budget revenues. ${ }^{1}$

On the basis of earlier studies (quoted in the previous section), the following research questions $(\mathrm{Q})$ and hypothesis $(\mathrm{H})$ can be formulated to be tested in empirical models:

- Q1: Do changes in the tax rates in neighbouring municipalities induce similar changes in the analysed local jurisdiction?

- Q2: Are tax rates higher if the variation (measured by standard deviation, hereafter SD), among tax rates applied in neighbouring municipalities is higher?

- Q3: What are the factors influencing the appearance of local tax competition in relation to various local taxes? The hypothesis $(\mathrm{H} 1)$ assumes that competition is more likely if the tax base is mobile (vehicle tax) as well as in the case of taxes paid by business entities (property tax on businesses and vehicle tax) rather than by residents.

- H2: Local taxes constitute a minor part of budget revenues and they are also a small part of the tax burden imposed on citizens and businesses. Therefore, tax policy may attract only limited interest from both sides (local politicians and tax-payers). Findings from other countries provide additional arguments supporting the claim of the limited extent of tax competition in Poland. Polish municipalities are relatively big (compared to, for example, Swiss, German or French municipalities). It may be expected that the competition will be greater in the case of suburbs of large urban agglomerations.

The issue of testing to what extent the rates in an analysed municipality are dependent on the level of rates in neighbouring local governments is complex. It is known from other research that the level of tax rates depends on several other characteristics of the local environment, such as population size, the wealth of the local community, and so on. In some cases, these other explanatory variables are related to the features connected to the location of the local jurisdiction. In particular, this concerns the distance from major agglomerations. In suburb municipalities taxes are 
often higher than elsewhere, because local governments may tax the location rent. As a consequence, even if there is a positive correlation between the tax level in the analysed municipality and tax levels in neighbouring local governments, it is not certain whether that relationship can be attributed to tax competition, or rather to the 'common location' (for example, the vicinity of a large urban centre). That relationship is investigated through the Hierarchical Multiple Regression model, which allows a fixed order of entry to be specified for variables in order to control for the effects of covariates and to test the effects of certain predictors independent of the influence of others. In the model, correlation with neighbouring tax rates will be controlled by the distance from agglomerations and other factors. The model being tested can be summarized in the following equation:

$T R(i)=f(\overline{N T R}, \sigma(N T R), L E(i))+\varepsilon$

Where:

$T R(i)$ - tax rate in municipality $i$

$\overline{N T R},-$ mean of tax rates in neighbouring municipalities $\left(\overline{N T R}=\frac{\sum_{j=1}^{n} T R(j)}{n}\right.$, where $n-$ number of municipalities which are neighbours of municipality $i)$

$\sigma(N T R)-S D$ of tax rates among neighbouring municipalities

$L E(i)$ - local environment measured by population size, wealth of local community and distance from large agglomeration centres $\varepsilon-$ residual.

The presented tests are conducted for four local taxes:

- Property tax from physical persons, which in practice means housing properties of local inhabitants;

- $\quad$ Property tax from legal entities, i.e. business (commercial) properties;

- Tax on agriculture, paid by farmers and depending on farm size and quality of soil;

- Vehicle tax, which is levied on busses and lorries only (but not on passenger cars, motorcycles, or tractors used for farming), i.e. it is paid by some types of businesses.

Property tax provides about three quarters of all the 'discretionary revenues' (or over $12 \%$ of the total budget revenues) of municipal governments. More than four fifths of its tax yields are collected from business properties, while residential properties are taxed with very low tax rates and provide less than one fifth of the revenues from tax. Vehicle tax (providing less than $1 \%$ of total municipal revenues) is interesting because of its relatively mobile tax base. Therefore, tax competition can be expected in relation to this local tax, although, on the other hand, the low significance of this tax for total budget revenues and the very limited number of potential tax-payers may reduce the interest in policies related to this tax. Tax on agriculture is important in traditional rural local governments (although in the scale of the whole country it provides just below $2 \%$ of municipal revenues). Moreover, in some rural areas it is the only tax paid by the majority of voters. For several rural tax-payers, the tax on agriculture constitutes a heavier tax burden than the tax on housing property.

In the case of property tax from legal entities, there is no tax mobility in the literal sense - the migration of a given property is impossible. But changes in the location of business activity driven by the local tax rates are likely to happen. Therefore, tax competition efforts of local governments may be expected which concentrate on positive spillover for the local budget through higher income tax revenues from employees of the re-located company.

In the case of tax on agriculture and housing property tax, the mobility of the tax base is very low or non-existent, although Tiebout's classic 'voting with the feet' model (1956) referred originally to the migration of residents. But in practice, such migration is very unlikely to happen, especially in a situation where the property tax is very low (in Poland, the maximum rate per square meter of housing property is less than 0.25 euros). As shown by the conclusions of Dowding \& Feiock (2012), empirical evidence for the tax migration of citizens is also weak in other countries in which tax rates on housing properties are much higher than in Poland.

If evidence for tax competition is to be found in Poland, it is expected that, in the case of vehicle tax and commercial property tax, the dominant motive would be the stimulation of local economic development. However, in the case of the two other taxes, the potential motive would be related to 'yardstick competition' and the desire to maintain political capital.

The empirical test was conducted for municipalities located in three different Polish regions: the Lublin region in Eastern Poland (213 municipalities), the Lower Silesia region with a capital in Wrocław, located in South-Western Poland (169 municipalities), and the Western Pomeranian region with a capital in Szczecin, located in North-Western Poland (114 municipalities).

\section{Results of empirical tests}

From interviews conducted with local politicians in 36 Polish municipalities, we know that tax rates in neighbouring municipalities are an important topic of debate related to voting on tax resolutions in the local councils (Swianiewicz 2015). Almost half of the respondents declared that tax rates in other local governments have an impact on their own decisions (see Table 1).

The tax competition tests start with a basic analysis of correlation coefficients. ${ }^{2}$ Table 2 shows that the rate of the local tax is in most cases significantly and positively correlated with the rate in neighbouring municipalities. However, in opposition to the earlier expectation $(\mathrm{H} 1)$, the relationship is stronger in the case of property tax from physical persons and (especially) tax on agriculture. Vehicles tax is at the other extreme - the correlation is very weak. The correlations are also weaker for tax

Table 1. Percentage of those who answer 'important' to the question of the significance of tax rates in other local governments for decisions in the respondent's municipality $(N=110)$.

\begin{tabular}{|c|c|c|c|c|}
\hline & $\begin{array}{c}\text { Tax on housing } \\
\text { properties }\end{array}$ & $\begin{array}{c}\text { Tax on commercial } \\
\text { properties }\end{array}$ & $\begin{array}{c}\text { Tax on } \\
\text { agriculture }\end{array}$ & Vehicle tax \\
\hline All respondents & $46 \%$ & $48 \%$ & $48 \%$ & $12 \%$ \\
\hline Mayors & $35 \%$ & $41 \%$ & $42 \%$ & $12 \%$ \\
\hline Local treasurers & $52 \%$ & $52 \%$ & $55 \%$ & $17 \%$ \\
\hline Councillors & $49 \%$ & $48 \%$ & $47 \%$ & $9 \%$ \\
\hline
\end{tabular}

Note: Percentages are rounded to integer values

Source: Swianiewicz 2015. 
on commercial properties than for tax on housing properties. This all suggests that, if there is competition, it is mostly in the form of 'yardstick competition' rather than 'classic' competition for a mobile tax base.

Table 3 demonstrates that the relationship between the level of tax rate and the variation of rates among neighbours is much weaker than that between the tax rate level and the mean rates in neighbouring municipalities. Only a little over half of the coefficients show any significance, but all of them are in the expected direction.

It was expected that a change in the tax rate may induce similar changes in neighbouring municipalities. However, the correlations are very low and usually insignificant (Table 4). This is the weakest part of the test. With the exception of tax on agriculture (where the 'yardstick competition' seems to be the strongest), a change in the tax rate seems not to be significantly related to changes in neighbouring local government units. But the test is very simplistic in this respect - it covers only one timespan (2009-2012), while in fact a full analysis would require a much more complex time-series analysis. This could be the topic of a more thorough study in the future.

In summary, the simple Pearson correlations analysis provides only limited proof of tax competition. The most intriguing correlations are those between the level of tax rates in neighbouring municipalities. However, it is not clear whether the similarities could simply be attributed to tax competition between municipalities with a similar location, which leads them to apply similar tax policies. This is checked through the regression models. If similarity of tax rates is caused more by similar conditions than purely the 'neighbouring factor', then the variation should be better explained by factors such as the affluence of the local community (measured by the per capita local tax base) or the distance from large urban agglomerations. However, if the impact of the neighbourhood remains significant after including the other controlling variables in the model, it may mean that tax competition plays some role in explaining the variation in tax policies. The models are built separately for each of the taxes. The dependent variables are the local tax rates, while the list of independent variables includes two which are related to potential tax competition (the tax rates in neighbouring municipalities and the SD of tax rates in neighbouring municipalities) and three related to the broader context in which tax policies are adopted (population size, affluence of the local community, and distance from a large urban agglomeration). The results of the test are presented in table 5.

The explanatory power of the constructed models differs depending on the tax. The best predictions of the tax rates are obtained in the case of agriculture tax and the worst for vehicle tax. Property tax is in between, with rates for housing properties explained better by the models than rates levied on commercial properties.

However, in general, the results presented in table 5 confirm that the variables which may be identified with the presence of tax competition are often powerful predictors of the variation of the local tax rates. The average tax rate from the tax rates in neighbouring municipalities remains the most powerful explanatory factor in all the tested models.

The SD of neighbouring local government units happens to be a significant independent variable as well, although only in some of the models. It was expected that it may be easier to increase the tax rate if the variation among neighbours is higher, since the variation makes comparisons more difficult for the average taxpayer, and therefore the pressure of the 'yardstick competition' might be lower. That expectation has been confirmed to a limited extent only. The relationships are not very strong and they do not apply to all local taxes.
Table 2. Correlations between local tax rates and mean rates in neighbouring municipalities (all 3 regions, $N=496$ ).

\begin{tabular}{|c|c|c|}
\hline & $\mathbf{2 0 1 2}$ & $\mathbf{2 0 0 9}$ \\
\hline property tax from physical persons 2009 & +0.491 & +0.505 \\
\hline property tax from physical persons 2012 & +0.503 & +0.524 \\
\hline property tax from legal entities 2009 & +0.444 & +0.453 \\
\hline property tax from legal entities 2012 & +0.452 & +0.455 \\
\hline tax on agriculture 2009 & +0.715 & +0.712 \\
\hline tax on agriculture 2012 & +0.731 & +0.741 \\
\hline vehicle tax 2009 & +0.220 & +0.223 \\
\hline vehicle tax 2012 & +0.221 & +0.236 \\
\hline
\end{tabular}

Note: All correlations are significant at the 0.001 level Source: own calculations based on budget execution reports.

Table 3. Correlations between tax rates and $S D$ of rates in neighbouring municipalities (all 3 regions, $N=496$ ).

\begin{tabular}{|c|c|}
\hline property tax from physical persons 2009 & $-0.434^{* * *}$ \\
\hline property tax from physical persons 2012 & $-0.454^{* * *}$ \\
\hline property tax from legal entities 2009 & $-0.311^{\text {** }}$ \\
\hline property tax from legal entities 2012 & $-0.326^{\text {** }}$ \\
\hline tax on agriculture 2009 & $-0.095^{*}$ \\
\hline tax on agriculture 2012 & \\
\hline vehicle tax 2009 & \\
\hline vehicle tax 2012 & \\
\hline
\end{tabular}

Note: blank spaces mean no significant correlation. * correlation significant at the 0.05 level. ${ }^{* *}$ - significant at the 0.01 level. ${ }^{* * *}$ - significant at the 0.001 level

Source: own calculations based on budget execution reports.

Table 4. Correlations between changes in tax rates and changes in the tax rates of neighbouring municipalities (2009-2012 change).

\begin{tabular}{|c|c|}
\hline & All 3 regions $(\mathbf{N}=\mathbf{4 9 6})$ \\
\hline property tax from physical persons & \\
\hline property tax from legal entities & \\
\hline tax on agriculture & $+0.161^{* * *}$ \\
\hline vehicle tax & \\
\hline
\end{tabular}

Note: blank spaces mean no significant correlation, * correlation significant at the 0.05 level, ${ }^{* *}$ - significant at the 0.01 level, ${ }^{* *}$ - significant at the 0.001 level

In all tested models, adding the block of two variables (the average tax rate and SD of tax rates among neighbouring municipalities) to the model increases the model's predictive capacity in a statistically significant way.

In the case of tax on agriculture (where the relationship is the most significant), an increase of tax by 1 percentage point in neighbouring municipalities results in an increase of tax in the analysed municipality by 0.9 of a percentage point. The estimated value of the tax rate is expressed by the equation:

$T R A(i)=0.9^{*} \overline{T R A N}+0.00007 * P S(i)+9.3+\varepsilon$

where:

$T R A(i)$ - rate of tax on agriculture in municipality $i$

$\overline{T R A N}$ - mean rate of tax on agriculture in neighbouring municipalities

$P S(i)$ - population size of municipality $i$

$\varepsilon-$ residual 
Table 5. Regression models explaining municipal tax policies in the three Polish regions $(N=496)$.

\begin{tabular}{|c|c|c|c|c|}
\hline \multicolumn{5}{|c|}{ Property tax from physical persons } \\
\hline & \multicolumn{2}{|l|}{2012} & \multicolumn{2}{|c|}{2009} \\
\hline & $\mathrm{R}^{2}$ & Sign. & $\mathrm{R}^{2}$ & Sign. \\
\hline & 0.319 & 0.000 & 0.275 & 0.000 \\
\hline & $\mathrm{R}^{2}$ change & Sign. $F$ change & $\mathrm{R}^{2}$ change & Sign. $\mathrm{F}$ change \\
\hline & 0.240 & 0.000 & 0.245 & 0.000 \\
\hline & Beta & Sign. & Beta & Sign. \\
\hline \multicolumn{5}{|l|}{ Affluence of local community } \\
\hline Population size & 0.132 & 0.001 & 0.097 & 0.013 \\
\hline \multicolumn{5}{|l|}{ Distance to agglomeration } \\
\hline Tax rate in neighbourhood & 0.390 & 0.000 & 0.357 & 0.000 \\
\hline SD in neighbourhood & -0.158 & 0.002 & -0.193 & 0.000 \\
\hline \multicolumn{5}{|c|}{ Property tax from legal entities } \\
\hline \multicolumn{3}{|c|}{2012} & \multicolumn{2}{|c|}{2009} \\
\hline & $\mathrm{R}^{2}$ & Sign. & $\mathrm{R}^{2}$ & Sign. \\
\hline & 0.228 & 0.000 & 0.216 & 0.000 \\
\hline & $\mathrm{R}^{2}$ change & Sign. F change & $\mathrm{R}^{2}$ change & Sign. $\mathrm{F}$ change \\
\hline & 0.186 & 0.000 & 0.188 & 0.000 \\
\hline & Beta & Sign. & Beta & Sign. \\
\hline \multicolumn{5}{|l|}{ Affluence of local community } \\
\hline Population size & & & & \\
\hline Distance to agglomeration & & & & \\
\hline Tax rate in neighbourhood & 0.381 & 0.000 & 0.384 & 0.000 \\
\hline SD in neighbourhood & -0.115 & 0.015 & -0.114 & 0.015 \\
\hline & & n agriculture & & \\
\hline & 2012 & & & \\
\hline & $\mathrm{R}^{2}$ & Sign. & $\mathrm{R}^{2}$ & Sign. \\
\hline & 0.570 & 0.000 & 0.543 & 0.000 \\
\hline & & Sign. $F$ change & $\mathrm{R}^{2}$ change & Sign. $\mathrm{F}$ change \\
\hline & & 0.000 & 0.451 & 0.000 \\
\hline & Beta & Sign. & Beta & Sign. \\
\hline Affluence of local community & & & & \\
\hline Population size & 0.127 & 0.000 & 0.158 & 0.000 \\
\hline Distance to agglomeration & & & & \\
\hline Tax rate in neighbourhood & 0.728 & 0.000 & 0.695 & 0.000 \\
\hline SD in neighbourhood & & & -0.085 & 0.006 \\
\hline & & ehicle tax & & \\
\hline & 2012 & & & \\
\hline & $\mathrm{R}^{2}$ & Sign. & $\mathrm{R}^{2}$ & Sign. \\
\hline & 0.069 & 0.000 & 0.067 & 0.000 \\
\hline & & Sign. $F$ change & $R^{2}$ change & Sign. $F$ change \\
\hline & & 0.000 & 0.056 & 0.000 \\
\hline & Beta & Sign. & Beta & Sign. \\
\hline Affluence of local community & & & & \\
\hline Population size & & & & \\
\hline Distance to agglomeration & & & & \\
\hline Tax rate in neighbourhood & 0.247 & 0.000 & 0.243 & 0.000 \\
\hline SD in neighbourhood & & & -0.107 & 0.020 \\
\hline
\end{tabular}

Note: Beta coefficients are quoted only in the case of a relationship significant at the 0.05 level. Blank spaces mean no significant impact of the variable.

Source: own calculations. 
MISCELLANEA GEOGRAPHICA - REGIONAL STUDIES ON DEVELOPMENT

Vol. $20 \cdot$ No. $3 \cdot 2016 \cdot$ pp. 37-43 • ISSN: 2084-6118 • DOI: 10.1515/mgrsd-2016-0018

Table 6. Changes in rates of vehicle tax and changes in tax revenues in selected Polish municipalities.

\begin{tabular}{|c|c|c|c|}
\hline Municipality & Region & Change in tax rate in the period 2007-2009 & $\begin{array}{c}\text { Change in revenues from tax in the period } \\
\mathbf{2 0 0 7 - 2 0 1 2}\end{array}$ \\
\hline Jaktorów & Mazovia & From 66 to $42 \%$ of maximum rate & From 0.3 to 9.5 million PLN \\
\hline Radzymin & Mazovia & From 86 to $48 \%$ of maximum rate & From 0.2 to 1.5 million PLN \\
\hline Teresin & Mazovia & From 59 to $13 \%$ of maximum rate & From 0.03 to 0.17 million PLN \\
\hline Miękinia & Lower Silesia & From 79 to $50 \%$ of maximum rate & From 0.2 to 1.5 million PLN \\
\hline
\end{tabular}

Source: own calculations based on budget execution reports.

The results of the analysis suggest that 'yardstick competition', helping to maintain political capital, seems to play a more important role than 'classic' competition for the tax base.

The poor statistical evidence for tax competition in the case of vehicle taxation merits more careful reflection. The expectations in that respect were ambiguous. On the one hand, it is a tax providing a very small proportion of local revenues, so it may be expected that competition would make little sense. But, on the other hand, there are factors which could strengthen tax competition. Firstly, the tax base is more mobile than the other local taxes considered. Secondly, since the revenues involved are small, decisions about changes in the tax rate are relatively easy, as they do not cost much for the local budget. Data from the regression models suggests that, statistically, competition related to vehicle tax is difficult to trace. But this does not exclude individual cases in which local governments concentrate on that tax. Indeed, particular municipalities can be identified in which the phenomenon seems to exist and, moreover, seems to result in the mobility of the tax base (reflected in the considerable growth of revenues in spite of the decrease in the tax rate). In particular, four intriguing cases are briefly characterized in table 6 .

It is interesting to note that all of the municipalities enumerated in table 6 have some common features. Firstly, they are located close to large urban agglomerations, where the tax competition is expected to be more developed. The density of economic activities is larger, so attracting new businesses is more likely (the transaction costs of tax mobility are lower). This finding echoes the results of earlier studies conducted in other European countries. Secondly, all of the identified standout cases are relatively small local governments - Radzymin has fewer than 24,000 citizens, and the remaining three municipalities have fewer than 15,000 . The theory of tax competition applied to sovereign states, drawing from games theory, suggests that the lowering of tax rates is more likely in small countries, since attracting new tax payers 'makes a difference' to a larger extent than in bigger countries. The difference is due to agglomeration rents in the larger jurisdictions and the more open economies of the smaller units. Empirical observation suggests that the same rule may be applied to subnational local jurisdictions.

\section{Conclusions}

Even if the discretion of municipal governments in Poland over local tax rates is limited, the theory of local tax competition has proved to be useful for the explanation of the variation in tax policies among Polish local jurisdictions. Significant statistical evidence of policies which take into account tax rates in neighbouring jurisdictions, and which seem to reflect the tax competition phenomenon, has been found through the conducted tests. The level of tax rates is statistically correlated with tax burdens in neighbouring jurisdictions, and the relationship remains significant even when it is controlled by other potential explanatory variables (related to the location rent and affluence of local communities). In some models, a statistical relationship between the level of tax rates and the SD of tax rates in neighbouring municipalities was also found. This finding confirms expectations based on the theoretical assumptions presented in the first sections of this paper.

However, contrary to earlier expectations $(\mathrm{H} 1)$, the statistical evidence of tax competition is strongest not in the case of tax with a mobile tax base, but in the case of tax on agriculture, followed by tax on housing properties. This suggests that the competition is more related to the 'yardstick competition', rooted in political (electoral) motives, than classic competition for a mobile tax base. That is not to say that competition for a mobile base of vehicle tax does not exist in Poland at all. But such competition concerns relatively rare cases (some examples of which are quoted in the final paragraphs of the previous section of this article) which cannot be grasped by statistical analysis.

The cases collected for vehicle tax confirm hypothesis 2 $(\mathrm{H} 2)$, which suggested that tax competition would be more extensive in local governments located in the suburbs of large urban agglomerations.

It is important to remember that the reduction of local tax rates in Poland usually results in lower budget revenues. Visible stimulation (through attracting new companies), or the spillover effect, can only be noticed in rare, individual cases.

\section{Acknowledgment}

The paper is based on the results of the 'Local Tax Policies as Instruments in Development Competition' research project. The project is funded by Narodowe Centrum Nauki (National Science Centre) grant number 206427.

\section{Notes}

1. A more detailed description of the Polish local tax system may be found in Swianiewicz, Łukomska 2015.

2. In our interpretation of correlation coefficients we concentrate primarily on their statistical significance (t test), which tells us more about the importance of the result than the absolute value of the $R$ coefficient (which is dependent on several factors, including sample size). 
Aalers, M \& Elhorst, JP 2005, 'Tax mimicking and yardstick competition among local governments in Netherlands', International Tax and Public Finance, vol. 12(4), pp. 495513.

Baur, M 2010, 'Harmonising Tax Base: Pros and Cons'. Paper presented at the OECD Conference on Tax Competition Between Sub-Central Governments, Bern 31.05-01.06.2010.

Blöchliger, H 2013, Fiscal federalism 2014: making decentralization work, Paris: OECD.

Blöchliger, H \& Pinero-Campos, J 2011, 'Tax Competition Between Sub-Central Governments', OECD Working Papers on Fiscal Federalism, no. 13, OECD Publishing.

Bodenstein, M \& Ursprung, H 2005, 'Political yardstick competition, economic integration, and constitutional choice in a federation: A numerical analysis of a contest success function model', Public Choice, vol. 124(3/4), pp. 329-352.

Brülhart, M \& Pratchet, R 2014, 'Alleged tax competition: the mysterious death of bequest taxes in Switzerland', Journal of Public Economics, vol. 111, pp. 63-78.

Buchanan, J \& Musgrave RA 1999, Public finance and public choice: two contrasting visions of the state, The MIT Press, Cambridge, MA - London.

Buglione, E \& Mare, M 2010, 'Tax Competition and Fiscal Federalism in Italy'. Paper presented at the OECD Conference on Tax Competition Between Sub-Central Governments, Bern, 31.05-01.06.2010.

Dafflon, B \& Rossi, S 2004, 'Tax competition between subnational governments: theoretical and regional policy issues with reference to Switzerland', in Finanzpolitik in der Kontroverse, eds E Hein, A Heise \& A Truger, Verlag, Marburg: Metropolis, pp. 227-250.

Dowding, K \& Feiock, R 2012, 'Intralocal competition and cooperation', in The Oxford Handbook of Urban Politics, eds K Mossberger, S Clarke \& P John, Oxford University Press, pp. 29-50.

Elschner, C \& Vanborren, V 2009, 'Corporate effective tax rates in an enlarged European Union', Taxation Papers, Luxembourg: Office for Official Publications of the European Communities.

François, I 2010, 'Sub-central tax competition: The French case'. Paper presented at the OECD Conference on Tax Competition Between Sub-Central Governments, Bern 31.05-01.06.2010.

Gérard, M, Jayet, H \& Paty, S 2009, 'Tax interactions among Belgian municipalities: Does language matter?, CESIFO Working Paper, no. 2558, February 2009.

Janeba, E \& Osterloch, S 2012, 'Tax and the city: a theory of local tax competition and evidence for Germany', ZEW Discussion Paper, no. 12-005, Manheim.

Kalb, A, Geys, B \& Heinemann, F 2012, 'Value for money? German local government efficiency in a comparative perspective', Applied Economics, vol. 44(2), pp. 201-218.
Kleven, H, Landais, C, Saez, E \& Schultz, E 2013, 'Migration and wage effects of taxing top earners: Evidence from the foreigners. Tax scheme in Denmark', NBER Working Paper, no. 18885, March 2013.

Lyytikäinen, T 2012, 'Tax competition among local governments: evidence from a property tax reform in Finland', Journal of Public Economics, vol. 96, pp. 584-595.

Miszczuk, A\& Miszczuk, M 1995, 'Próba typologii podatkowej gmin (na przykładzie województwa lubelskiego)', Wiadomości Statystyczne, vol. 5.

Moisio, A 2010, 'Tax competition among municipalities: The case of Finland'. Paper presented at the OECD conference on Tax Competition Between Sub-Central Governments, Bern 31.05-01.06.2010.

Mouritzen, PE 1992, 'What is a fiscal crisis?' in Managing cities in austerity: urban fiscal stress in ten western countries, ed PE Mouritzen, Sage, London-Newbury Park-New Delhi.

Oates, W 1972, Fiscal Federalism, Harcourt, Brace and Jovanovic, New York.

Podstawka, M \& Rudowicz, E 2010, 'Wykorzystanie wybranych podatków lokalnych w kreowaniu polityki fiskalnej gmin', Zeszyty Naukowe SGGW: Polityki Europejskie, Finanse $i$ Marketing, vol. 4 (53), pp. 79-87.

Ratts $\varnothing$, J 2005, 'Local tax Financing in the Nordic Countries', Yearbook of Nordic Tax Research, pp. 33-50.

Reulier, E \& Rocaboy, Y 2009, 'Regional tax competition: evidence from French regions', Regional Studies, vol. 43(7), pp. 915-922.

Sedmihradská, L \& Bakoš, E 2016, 'Municipal tax autonomy and tax mimicking in Czech municipalities', Lex localis-Journal of Local Self-Government, vol. 14(1), pp. 75-92.

Šević, Ž 2008, Local public finance in Central and Eastern Europe, Edward Elgar, Cheltenham.

Skica T, Kiebała, A \& Wołowiec, T 2011, 'Stymulowanie lokalnej konkurencyjności gmin na przykładzie podatków od środków transportowych', Studia Regionalne i Lokalne, vol. 2(44), pp. 118-139.

Swianiewicz, P 2014, 'An empirical typology of local government systems in Eastern Europe', Local Government Studies, vol. 40(2), pp. 292-311.

Swianiewicz, P 2015, 'The politics of local tax policy making in Poland'. Paper presented at the NISPAcee Annual Conference, Tbilisi, May 21-24, 2015.

Swianiewicz, P \& Łukomska, J 2015, 'Local tax policies in the limited autonomy of the revenue collection system in Poland', in Interaction between local expenditure responsibilities and local tax policy, eds K Junghun, J Lotz \& NJ Mau, Danish Ministry for Economic Affairs and the Interior and The Korea Institute of Public Finance, Rosendahls,

Tiebout, C 1956, 'A pure theory of local expenditures', Journal of Political Economy, vol. 64(5), pp. 416-424. 